\section{Influence of ICT integration on content preparation by ICT and Non-ICT trained teachers in secondary schools in Machakos County, Kenya}

\section{Rose Mwikali Kithungu}

$\mathrm{PhD}$ Candidate, University of Nairobi, Kenya

\section{Daniel Komo Gakunga}

$\mathrm{PhD}$, University of Nairobi, Kenya

\section{Musembi Nungu}

$\mathrm{PhD}$, University of Nairobi, Kenya

Submitted: 02 September 2020

Accepted: 05 November 2020

Published: 30 November 2020

Corresponding author:

Rose Mwikali Kithungu

DOI: 10.19044/esj.2020.v16n31p187

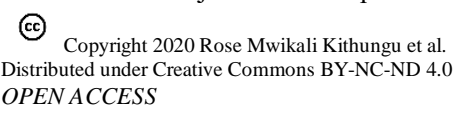

\begin{abstract}
The use of Information Communication Technology (ICT) in teaching and learning has become a necessity and an opportunity for improving and enhancing acquisition of knowledge by learners. The integration of ICT in teachers' pedagogical practices has the potential to transform the teaching and learning process. ICTs have become vital tools for teachers to enhance learning through the teachers' pedagogical aspect of content preparation in classroom. The purpose of this study was to investigate the influence of ICT integration on content preparation by ICT and Non-ICT trained teachers in secondary schools. The study's specific objectives were to assess the status of teachers' integration of ICT in content preparation and to establish the influence of ICT integration on content preparation by ICT and Non-ICT trained teachers in secondary schools. The hypothesis of the study was; ICT integration does not significantly influence content preparation by ICT and Non-ICT trained teachers in secondary schools in Machakos County, Kenya. The study employed descriptive survey research design. The sample size comprised of 180 principals, 360 teachers and 398 students. Data was collected using questionnaires, observation schedule, and document analysis. Content validity of the research instruments was ascertained through analysis by experts in comparative education and piloting of the research instruments. Reliability was ascertained by testing and re-testing the instruments. Data analysis was done by use of the Statistical Package for Social Sciences (SPSS). Responses from the observation schedule and document
\end{abstract}

How to cite this article

Kithungu, R.M.. et al, (2020). Influence of ICT integration on content preparation by ICT and Non-ICT trained teachers in secondary schools in Machakos County, Kenya. European Scientific Journal, ESJ, 16(31), 187. https://doi.org/10.19044/esj.2020.v16n31p187 
analysis guide were organized into themes and integrated with rest of the data for purposes of triangulation. Pearson's Product Moment correlation coefficient was used to determine the level and strength of the relationship between ICT integration and teachers' content preparation. Pearson chi test was employed to determine the levels of significance between the variables. The study established that ICT trained teachers profoundly embraced the use of ICT skills to prepare e-based learning activities which enhanced their content preparation leading to more innovative lessons due to the acquisition of pedagogical ICT training. The study concluded that ICT integration significantly influenced teachers' content preparation by ICT and Non-ICT trained teachers. ICT trained teachers' integration of ICT in their content preparation was significantly higher at (p) 0.002 than their Non-ICT trained counterparts at (p) 0.045 . It was concluded that ICT trained teachers integrated ICT in their content preparation more than Non-ICT trained teachers in secondary schools. Hence the null hypothesis was rejected. Based on the findings and conclusions the study recommended that, The Ministry of Education (MOE) and other ICT training agencies should provide ICT in-service training programs to ensure that all teachers acquire ICT skills to utilize ICT in content preparation for quality education.

Subject: Education

Keywords: ICT integration, content preparation, pedagogical practices, ICT trained teachers, Non-ICT trained teachers

\subsection{Introduction}

In the recent three decades, progressive education systems have prioritized the use of Information Communication Technology (ICT) as a salient strategy that has had the capability to change teachers' pedagogical operations (Kozma \& Vota, 2014). This has been based on several researches that have identified ICT as a pivotal feature of educational innovation and change. According to Ifenthaler and Schweinbenz, (2013) many countries, particularly in the developed world, have reported tangible improvements on teaching and learning following the integration of ICT in teachers' pedagogical practices. In addition developed and developing countries have attested to the fact that ICT ought to be a constituent of teachers' pedagogical practices to improve the quality of teaching and learning.

Though conventional pedagogy has shown greater educational improvements over time, the integration of ICT in teachers' pedagogical practices is believed to exhibit more significant achievements in education worldwide. According to Robinson and Latchem, (2013) education policymakers have acknowledged that for citizens to overcome the $21^{\text {st }}$ Century demands they must be in a position to communicate, access information, and use emerging technologies, hence ICT must be an integral part of educational pedagogy. ICT integration in education necessitates the 
incorporation of Information Communication Technologies (ICTs) in pedagogy to support and intensify the acquisition of suitable competencies within learners, which include; skills, knowledge, attitudes, and values to manage learning effectively (Heick, 2016). Pedagogy, broadly defined, entails the didactic approach and strategies that permit learning to take place, while teachers' pedagogical practices are teachers' actions and discourses that define the interaction between the teacher and the learners (Amuko, 2015).

An efficacious application of ICT in pedagogy improves teachers content preparation as well as facilitating learners' access to knowledge and developing within them higher order thinking skills, accessing variant information from the internet, increased students problem solving skills, participation in the learning process, and collaboration with other students (Heick, 2016). The World Education Forum held in Dakar, Senegal, in April 2002, recommended the utilization of ICT in teaching and learning to improve the quality of education and ensure the attainment of recognized and measurable learning results. In their quest to attain the Sustainable Development Goals (SDGs), both developed and developing countries globally embarked on educational reforms aimed at embedding ICT in educational practice (UNESCO, 2015). Teachers play a cardinal role in education; hence they require specialized ICT training to acquire skills and knowledge for appropriate incorporation of technology in their content preparation and pedagogy in general. Passi (2014) posited that, many teacher training institutions across the world had undergone structural changes in their training content due to rapid technological development to ensure that they produce teachers who can apply technology in the classroom. These initiatives resulted to the production of ICT trained teachers competent to integrate ICT in their instructions.

Countries that have fully trained their teachers on ICT and exploited the prospective use of technology in education and pedagogy, mainly in the global north, have attained significant knowledge development (Tabira \& Otieno, 2017). Ishizuka (2013) found out that in the United States the International Society for Technology in Education (ISTE) provided guidelines and standards for ICT training of teachers to ensure effective integration of ICT in the learning environment at all levels. These ICT trained teachers used and applied technology in content preparation and all aspects of teaching and learning leading to the production of globally competitive learners. Studies done by Ateş, Çerçi and Derman, (2015) in Turkey indicated that though teachers were offered pre-service and in-service ICT training; the in-service courses based more on the acquisition of basic ICT skills than utilization in teaching and learning. Therefore, the Non-ICT trained teachers in Turkish schools lacked adequate pedagogic training on technology use in pedagogy which limited their content preparation. On the contrary, the ICT trained 
teachers who had acquired pre-service ICT training on technology application in pedagogy exhibited improved and enriched methods of content preparation thus improved students' performance (Ateş, Çerçi and Derman, 2015).

Most African countries have embarked on educational reforms aimed at ICT integration in pedagogy and have drafted and approved ICT policies in education; in addition, they have established pre-service and in-service ICT training modules to ensure that educators gain knowhow on ICT based pedagogy to prepare globally competitive learners (Greaves, 2012). In Ghana ICT initiatives, aimed at improving educational achievements by reforming secondary education through integration of ICT in teachers' pedagogical practices. The education department endeavored to assimilate technology in pre-service and in-service teacher training for full employment of ICT in teaching and enhance learning; this initial training promoted digital literacy more than the construction of technology based instructional materials (Greaves, 2012).

As a result the Non-ICT trained teachers were unable to select relevant ICT tools, access, and appraise educational materials from variant sources for content preparation thus lowering the quality of teaching and learning. Comparatively the ICT trained teachers who had exposure to either pre-service or in-service ICT training demonstrated command on the adoption and integration of ICT in their teaching operations; consequently this resulted to increased students problem solving skills, access to expansive content and educational ideas, creativity and motivation amongst learners (Liu, 2011). Hennesy, David and Wamakote (2010) found out that East African countries, Tanzania, Uganda, among others had made the teaching profession a centre of focus due to technological advancements, expansion of knowledge, coupled with globalization. Passi (2014) asserted that despite lack of structured preservice ICT training, efforts had been made to expose teachers to in-service pedagogical ICT training to promote the incorporation of technology in their classroom operations. This implied that majority of educators in the East African region were dearth of ICT proficiency for full usage of ICT in their pedagogical practices.

In Kenya, the use of ICT is fore grounded as a key driver of the country's vision 2030. The education sub-sector, in the vision 2030 social tower, aims at providing internationally competitive and quality education and research for sustainable development (MOE, 2013). This goal will be fulfilled by amid others, implementing Kenya's National ICT Policy. The policy aims at streamlining ICT integration in the teaching curriculum, establishing eeducation networks, and promoting e-learning at all levels of education. The Ministry of Education (MOE) has embarked on initiatives to support and promote ICT incorporation in education and utilization in pedagogy (MOE, 2013). Teacher training institutions have incorporated ICT education in their 
pre-service training curriculum with more emphasis on teaching with technology rather that teaching about technology, to produce ICT trained teachers. In addition, the Ministry of Education in partnership with other ICT development partners have organized in-service training programmes to enable Non-ICT trained teachers incorporate ICT in their pedagogy (Kombo, 2013).

Despite the MOE commitment to ICT integration in pedagogy; Kenya being a developing country is struggling towards the realization of full ICT integration in education and teachers pedagogical practices in particular. The initiative has been hindered by insufficient ICT infrastructural facilities, the focus of ICT as a subject rather than a pedagogical tool, coupled up with inadequate ICT training of teachers, thus, the presence of ICT and Non-ICT trained teachers in Kenyan secondary schools. This signifies that the integration and application of ICT in the teaching and learning process in the education sector in Kenya, and particularly in secondary schools is still in its infancy. However, in Africa generally, and in Kenya in particular, there has been little research to assess how the integration of ICT has impacted on teachers' content preparation. This study sought to address this gap by examining how ICT integration influences content preparation of teachers in public secondary schools in Machakos County, Kenya

\subsection{Statement of the problem}

Utilization and integration of ICTs in pedagogy catalyzes and transforms teachers' pedagogical practices and ensures productive teaching and learning. This can be attained through professionally developing teachers who can conveniently integrate technology in their pedagogical practices and particularly in content preparation. In Kenya, the Ministry of Education has prioritized ICT integration in teaching through the inclusion of ICT education in teacher training institutions for the inclusion of ICTs in secondary school pedagogy. In addition the MOE has partnered with other development agencies in an endeavor to provide ICT in-service training to secondary school teachers to facilitate the incorporation of ICT in their didactics. However, the initiative has faced challenges such as; inadequate ICT training which has prioritized provision of technological literacy than ICT based pedagogy to enable teachers entirely integrate ICT in their instructions, inadequate ICT facilities, and the target of ICT as a subject rather than a tool for curriculum strengthening. This has led to low rate of ICT unification by teachers in Kenyan classrooms, which has inhibited the provision of quality education. Despite the immense efforts and resources directed towards the integration of ICT in education and pedagogy globally and more so in Kenya the highlighted setbacks have negatively imparted on the integration of ICT in teachers' content preparation in secondary schools. This implied that technological 
uptake by teachers and inadequate ICT training had created a lag between teachers' pedagogical behavior change and its actual integration in content preparation which was likely to affect the quality of education. Hence, the existence of ICT and Non-ICT trained teachers in Machakos County and variant ICT application in pedagogy which escalated the need for this study. In this regard, this study, sought to investigate the influence of ICT integration on teachers' content preparation of ICT and Non-ICT trained teachers in secondary schools in Machakos County, Kenya.

\subsection{Purpose of the study}

The purpose of this study was to investigate the influence of ICT integration on teachers' content preparation by ICT and Non-ICT trained teachers in secondary schools in Machakos County, Kenya.

\subsection{Objectives of the study}

The objectives of the study were to:

i) Assess the status of teachers' integration of ICT in content preparation by ICT and Non-ICT trained teachers in secondary schools in Machakos County, Kenya.

ii) Establish the influence of ICT integration on content preparation by ICT and Non-ICT trained teachers in secondary schools in Machakos County, Kenya.

\subsection{Research Hypothesis}

The study sought to test this null hypothesis: $\mathbf{H}_{1} \mathrm{ICT}$ integration does not significantly influence content preparation by ICT and Non-ICT trained teachers in secondary schools in Machakos County, Kenya.

\subsection{Review of Related Literature}

Successful integration of ICT in teachers' pedagogical practices impacts on the methods of content preparation by educators. According to Badri (2014) the use of ICT in pedagogy by ICT and Non-ICT trained teachers enhanced their ability to prepare schemes of work, lesson plans, lesson notes, lesson attendance sheets, records of work, and access to variant information for quality resources and innovative teaching and learning. Comprehensive integration of ICT in pedagogy transforms lesson planning and preparedness of teachers. Lee and Tsai (2010) opined that ICT and Non-ICT trained teachers used word processor to prepare lesson plans, schemes of work, records of work, and compile lesson materials; In addition they searched different sites for educational resources leading to quality course content and heightened pedagogical practices. A comparative study conducted by Sigales (2013) in 22 secondary schools in Singapore concluded that ICT trained teachers' 
application of technology in content preparation enabled the creation of multimedia based interactive and experimental instructional materials which catered for students with different learning abilities, enhanced access to a wide range of educational materials from online sources thus inclusive and quality education. A research done in Italy among 80 secondary school teachers which revealed that ICT trained teachers applied technology in lesson preparation which enabled them to easily access variant educational resources and resource formats including; audio clips, texts, images, and video/sound clips which made their subject content more simpler and innovative (Badri, 2014).

According to Tezci (2011) Non-ICT trained teachers were not sufficiently equipped with the skills to develop learning management software's which hindered the integration of technology in their content preparation. He further argued that high school teachers in Abu Dhabi region of United Arab reported lack of fundamental ICT skills as an impediment affecting their ability to use computer peripheral devices to prepare e-based learner-content interactive activities like PowerPoint presentations, audio/sound clips, video clips, images, and students' worksheets (Tezci, 2011). A study by Magbagbeola (2012) in Nigeria reported that Non-ICT trained teachers were deficient of ICT skills to plan technology lessons, sort educational software and explore internet sites for teaching materials, prepare PowerPoint slides, and images for class presentation which resulted to teacher centered classroom activities. The fore reviewed literature showed that ICT integration in teachers' pedagogical practices impacted on their content preparation. It was on this backdrop that this study was conceived to establish the influence of ICT integration on content preparation by ICT and Non-ICT trained teachers in secondary schools in Machakos County, Kenya.

\subsection{Research methodology}

The study employed descriptive survey design. The targeted population was 328 principals, 3600 teachers and 95,200 students. The universal target population was 99,128 respondents. The study sampled; 180 principals, 360 teachers, and 398 students from the target population. The study embraced ratio proportionate sampling to get the sample size of the principals and teachers in each Sub-County. Equal allocation method was employed to choose the teachers and students in the sampled secondary schools. Data was collected using questionnaires, observation schedule, and document analysis. Content validity of the research instruments was ascertained through detailed comparative studies on the subject, review and analysis by expert in comparative education and piloting of the questionnaires. Test re-test technique was employed to enhance reliability of the instruments. Data analysis was done by use of the Statistical Package for Social Sciences (SPSS) programme. Responses from the observation schedule and document 
analysis guide were organized into themes and integrated with rest of the data for purposes of triangulation. Pearson's Product Moment was used to determine the level and strength of the relationship between ICT integration and teachers' content preparation. Pearson chi test was used to present and interpret the inferential data; and determine the levels of significance of the relationship between ICT integration and teachers' content preparation.

\subsection{Research findings}

The study sought to assess the status of teachers' integration of ICT in content preparation by teachers in secondary schools. In line with this objective, the respondents were asked to indicate their views on teacher's usage of ICT skills when preparing content for their lessons.

\subsection{Analysis of Principals', Teachers', and Students' views on teachers' use of ICT skills in content preparation}

The principals, teachers, and students were asked to indicate their level of agreement on teachers' use of ICT skills in content preparation. They were requested to indicate their responses as; $\mathrm{SA}=\mathrm{Strongly}$ Agree, A=Agree, $\mathrm{D}=$ Disagree, and $\mathrm{SD}=\mathrm{Strongly}$ Disagree. The results of the principals' views on teachers' use of ICT skills in content preparation were as contained in Table 4.1.

Table 4.1 Principal's views on teachers' use of ICT skills in content preparation

\begin{tabular}{|c|c|c|c|c|c|c|c|c|c|c|c|c|c|c|c|c|}
\hline \multirow{3}{*}{ Response } & \multicolumn{8}{|c|}{ ICT trained teachers } & \multicolumn{8}{|c|}{ Non-ICT trained teachers } \\
\hline & \multicolumn{2}{|c|}{ SA } & \multicolumn{2}{|c|}{$\mathbf{A}$} & \multicolumn{2}{|c|}{ D } & \multicolumn{2}{|c|}{ SD } & \multicolumn{2}{|c|}{ SA } & \multicolumn{2}{|c|}{$\mathbf{A}$} & \multicolumn{2}{|c|}{ D } & \multicolumn{2}{|c|}{ SD } \\
\hline & $\mathbf{n}$ & $\%$ & $\mathrm{n}$ & $\%$ & $\mathbf{n}$ & $\%$ & $\mathbf{N}$ & $\%$ & $\mathbf{n}$ & $\%$ & $\mathrm{n}$ & $\%$ & $\mathrm{n}$ & $\%$ & $\mathbf{n}$ & $\%$ \\
\hline $\begin{array}{l}\text { Teachers use ICT to } \\
\text { prepare schemes of work }\end{array}$ & 84 & 87.5 & 12 & 12.5 & 0 & 0 & 0 & 0 & 0 & 0 & 38 & 59.4 & 20 & 31.2 & 6 & 9.4 \\
\hline $\begin{array}{l}\text { Teachers use ICT to write } \\
\text { lesson plans }\end{array}$ & 84 & 87.5 & 12 & 12.5 & 0 & 0 & 0 & 0 & 0 & 0 & 0 & 0 & 26 & 40.6 & 38 & 59.4 \\
\hline $\begin{array}{l}\text { Teachers use ICT to write } \\
\text { lesson notes }\end{array}$ & 86 & 89.6 & 10 & 10.4 & 0 & 0 & 0 & 0 & 0 & 0 & 0 & 0 & 31 & 48.4 & 33 & 51.6 \\
\hline $\begin{array}{l}\text { Teachers use ICT to } \\
\text { prepare records of work }\end{array}$ & 84 & 87.5 & 12 & 12.5 & 0 & 0 & 0 & 0 & 0 & 0 & 0 & 0 & 26 & 40.6 & 38 & 59.4 \\
\hline $\begin{array}{l}\text { Teachers use ICT to } \\
\text { research lesson content }\end{array}$ & 49 & 51 & 47 & 49 & 0 & 0 & 0 & 0 & 0 & 0 & 30 & 47 & 30 & 47 & 4 & 6 \\
\hline $\begin{array}{l}\text { Teachers use ICT to access } \\
\text { educational materials from } \\
\text { online data base (E.g. } \\
\text { Websites etc.) }\end{array}$ & 40 & 41.7 & 41 & 42.7 & 15 & 15.6 & 0 & 0 & 0 & 0 & 35 & 54.8 & 15 & 23.4 & 14 & 21.8 \\
\hline $\begin{array}{l}\text { Teachers use ICT to } \\
\text { prepare power point } \\
\text { presentations }\end{array}$ & 26 & 27.1 & 53 & 55.2 & 13 & 13.5 & 4 & 4.2 & 0 & 0 & 0 & 0 & 30 & 47 & 34 & 53 \\
\hline $\begin{array}{l}\text { Teachers use ICT to } \\
\text { prepare sound/audio clips } \\
\text { for lessons }\end{array}$ & 42 & 43.8 & 50 & 52.1 & 4 & 4.1 & 0 & 0 & 0 & 0 & 4 & 6.3 & 27 & 42.2 & 33 & 51.5 \\
\hline $\begin{array}{l}\text { Teachers use ICT to } \\
\text { prepare video clips for } \\
\text { lessons }\end{array}$ & 42 & 43.8 & 50 & 52.1 & 4 & 4.1 & 0 & 0 & 0 & 0 & 4 & 6.3 & 27 & 42.2 & 33 & 51.5 \\
\hline
\end{tabular}


Teachers use ICT to prepare images for lessons Teachers use ICT to prepare lesson attendance sheets

\begin{tabular}{llllllll|llllllll}
40 & 41.7 & 50 & 52.1 & 6 & 6.2 & 0 & 0 & 0 & 0 & 4 & 6.3 & 27 & 42.2 & 33 & 51.5 \\
42 & 43.8 & 50 & 52.1 & 4 & 4.1 & 0 & 0 & 0 & 0 & 4 & 6.3 & 27 & 42.2 & 33 & 51.5
\end{tabular}

Schools with ICT trained teachers $(\mathrm{n}=96 . \%=100)$

Schools with Non-ICT trained teachers $(n=64 . \%=100)$

The findings presented in Table 4.1 revealed that ICT trained teachers used ICT to prepare schemes of work, with 87.5 percent of the principals of schools with ICT trained teachers strongly agreeing with the statement, while none of the principals of schools with Non-ICT trained teachers strongly agreed with the statement. In addition 59.4 percent of the principals of schools with Non-ICT trained teachers agreed with the statement that teachers used ICT to prepare schemes of work compared to 12.5 percent of their counterparts who also agreed with the statement. None of the principals of schools with ICT trained teachers disagreed or strongly disagreed with the statement that teachers used ICT to prepare schemes of work compared to 31.2 percent and 9.4 percent of the principals of schools with Non-ICT trained teachers who disagreed and strongly disagreed with the statement respectively.

The analysis also revealed that 87.5 percent and 12.5 percent of the principals of schools with ICT trained teachers strongly agreed and agreed with the statement that teachers used ICT to write lesson plans, while none of the principals of schools with Non-ICT trained teachers indicated similar views. To the contrary, 40.6 percent and 59.4 percent of the principals of schools with Non-ICT trained teachers disagreed and strongly disagreed with the statement that teachers used ICT to write lesson plans, while none of their counterparts disagreed or strongly disagreed with the statement. None of the principals of schools with ICT trained teachers disagreed or strongly disagreed with the statement that teachers used ICT to write lesson notes compared to 48.4 percent and 51.6 percent of the principals of schools with Non-ICT trained teachers disagreed and strongly disagreed with the statement respectively. 89.6 percent and 10.4 percent of the principals of schools with ICT trained teachers strongly agreed and agreed with the statement that teachers used ICT to write lesson notes, while none of their counterparts indicated the same.

Further the data indicated that 87.5 percent of the principals of schools with ICT trained teachers strongly agreed with the statement that teachers used ICT to prepare records of work while none of the principals of schools with Non-ICT trained teachers strongly agreed with the statement. None of the principals of schools with ICT trained teachers disagreed or strongly disagreed with the statement that teachers used ICT to prepare records of work, 
compared to 40.6 percent and 59.4 percent of their counterparts who disagreed and strongly disagreed with the statement respectively. Similarly 49 percent of the principals of schools with ICT trained teachers and 47 percent of the principals of schools with Non-ICT trained teachers agreed with the statement that teachers used ICT to research lesson content. None of the principals of schools with ICT trained teachers disagreed or strongly disagreed with the statement that teachers used ICT to research lesson content compared to 47 percent and 4 percent of the principals of schools with Non-ICT trained teachers who had similar views respectively. None of the principals of schools with Non-ICT trained teachers strongly agreed with the statement that teachers used ICT to research lesson content compared to 51 percent of their counterparts who strongly agreed with the statement.

None of the principals of schools with Non-ICT trained teachers strongly agreed with the statement that teachers used ICT to access educational materials from online data base (E.g. Websites etc.) compared to 41.7 percent of the principals of schools with ICT trained teachers who strongly agreed with the statement. Similarly 42.7 percent of the principals of schools with ICT trained teachers and 54.8 percent of the principals of schools with NonICT trained teachers agreed with the statement that teachers used ICT to access educational materials from online data base (E.g. Websites etc.). 15.6 percent of the principals of schools with ICT trained teachers disagreed with the statement that teachers used ICT to access educational materials from online data base (E.g. Websites etc.) compared to 23.4 of their counterparts ho had similar views. 21.8 percent of the principals of schools with Non-ICT trained teachers strongly disagreed with the statement that teachers used ICT to access educational materials from online data base (E.g. Websites etc.), while none of their counterparts indicated the same.

The data further showed that 27.1 percent and 55.2 percent of the principals of schools with ICT trained teachers strongly agreed and agreed with the statement that teachers used ICT to prepare PowerPoint presentations, while none of the principals of schools with Non-ICT trained teachers had similar views. To the contrary, 47 percent and 53 percent of the principals of schools with Non-ICT trained teachers disagreed and strongly disagreed with the statement that teachers used ICT to prepare PowerPoint presentations, compared to 13.5 percent and 4.2 percent of the principals of schools with ICT trained teachers who disagreed and strongly disagreed with the statement.

In addition, 43.8 percent of the principals of schools with ICT trained teachers strongly agreed with the statements that teachers used ICT to prepare sound/audio clips for lessons and prepare video clips for lessons respectively, while none of the principals of schools with Non-ICT trained teachers strongly agreed with the statements respectively. 6.3 percent of the principals of schools with Non-ICT trained teachers agreed with the statements that 
teachers used ICT to prepare sound/audio clips for lessons and prepare video clips for lessons respectively, compared to 52.1 percent of their counterparts who agreed with the statements respectively. However, 42.2 percent of the principals of schools with Non-ICT trained teachers disagreed with the statements that teachers used ICT to prepare sound/audio clips for lessons and prepare video clips for lessons respectively; compared to 4.1 percent of their counterparts ho had similar views respectively. None of the principals of schools with ICT trained teachers strongly disagreed with the statements that teachers used ICT to prepare sound/audio clips for lessons and prepare video clips for lessons compared to 51.5 percent of their counterparts had similar views respectively.

None of the principals of schools with Non-ICT trained teachers strongly agreed with the statements that teachers used ICT to prepare images for lessons and prepare lesson attendance sheets respectively compared to 41.7 percent and 43.8 percent of the principals of schools with ICT trained teachers who strongly agreed with the statements respectively. In addition, 6.3 percent of the principals of schools with Non-ICT trained teachers agreed with the statements that teachers used ICT to prepare images for lessons and prepare lesson attendance sheets respectively, compared to 52.1 percent of their counterparts who indicated the same respectively. To the contrary, 42.2 percent of the principals of schools with Non-ICT trained teachers disagreed with the statements that teachers used ICT to prepare images for lessons and prepare lesson attendance sheets respectively, compared to 6.3 percent and 4.1 percent of their counterparts who disagreed with the statements respectively. In addition, 51.5 percent of the principals of schools with Non-ICT trained teachers strongly disagreed with the statements that teachers used ICT to prepare images for lessons and prepare lesson attendance sheets respectively, while none of their counterparts had similar views.

This connoted that ICT trained teachers' profoundly embraced the use of ICT skills to prepare e-based learning activities which enhanced their content preparation leading to more innovative lessons due to the acquisition of pedagogical ICT training. The position is supported by a research done in Italy among 80 secondary school teachers which revealed that ICT trained teachers applied technology in lesson preparation which enabled them to easily access variant educational resources and resource formats including; audio clips, texts, images, and video/sound clips which made their subject content more simpler and innovative (Badri, 2014).

Further the findings show that Non-ICT trained teachers lacked fundamental ICT skills to create multimedia based instructional materials like; PowerPoint presentations, sound/audio clips, video clips, and images for lessons which limited their integration of ICT in content preparation. These results supports a study conducted by Tezci (2011) which found that Non-ICT 
trained teachers were not sufficiently equipped with the skills to develop learning management software's which hindered the integration of technology in their content preparation; He further argued that high school teachers in Abu Dhabi region of United Arab reported lack of fundamental ICT skills as an impediment affecting their ability to use computer peripheral devices to prepare e-based learner-content interactive activities like PowerPoint presentations, audio/sound clips, video clips, images, and students' worksheets.

The analysis also implied that both ICT and Non-ICT trained teachers used ICT to prepare their professional documents, to research lesson content and to access educational materials from online sources to enhance their content preparation. These findings concurred with the assertion that the use of ICT in pedagogy by ICT and Non-ICT trained teachers enhanced their ability to prepare schemes of work, lesson plans, lesson notes, lesson attendance sheets, records of work, and access to variant information for quality resources and innovative teaching and learning (Badri, 2014).

In addition the teachers also were asked to indicate their level of agreement on their use of ICT skills in content preparation.

They were requested to indicate their responses as; $\mathrm{SA}=$ Strongly Agree, $\mathrm{A}=$ Agree, $\mathrm{D}=$ Disagree, and $\mathrm{SD}=$ Strongly Disagree. The results were as contained in Table 4.2.

Table 4.2 Teachers' views on their use of ICT skills in their content preparation

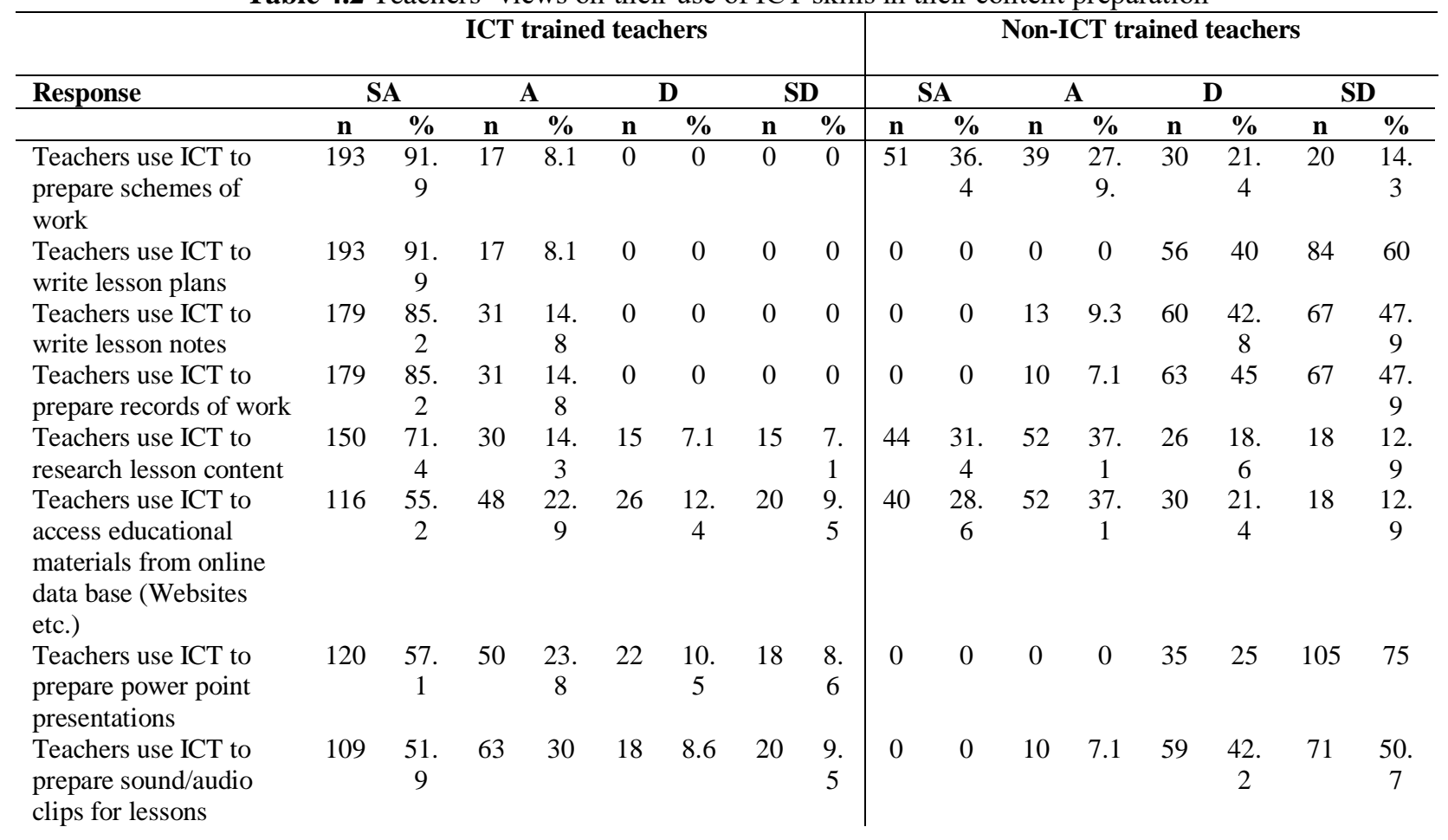




\begin{tabular}{|c|c|c|c|c|c|c|c|c|c|c|c|c|c|c|c|c|}
\hline $\begin{array}{l}\text { Teachers use ICT to } \\
\text { prepare video clips for } \\
\text { lessons }\end{array}$ & 109 & $\begin{array}{c}51 . \\
9\end{array}$ & 63 & 30 & 18 & 8.6 & 20 & $\begin{array}{c}9 . \\
5\end{array}$ & 0 & 0 & 10 & 7.1 & 59 & $\begin{array}{c}42 . \\
2\end{array}$ & 71 & $\begin{array}{c}50 . \\
7\end{array}$ \\
\hline $\begin{array}{l}\text { Teachers use ICT to } \\
\text { prepare images for } \\
\text { lessons }\end{array}$ & 109 & $\begin{array}{c}51 . \\
9\end{array}$ & 63 & 30 & 18 & 8.6 & 20 & $\begin{array}{l}9 . \\
5\end{array}$ & 0 & 0 & 10 & 7.1 & 59 & $\begin{array}{c}42 . \\
2\end{array}$ & 71 & $\begin{array}{c}50 . \\
7\end{array}$ \\
\hline $\begin{array}{l}\text { Teachers use ICT to } \\
\text { prepare lesson } \\
\text { attendance sheets }\end{array}$ & 109 & $\begin{array}{c}51 . \\
9\end{array}$ & 63 & 30 & 18 & 8.6 & 20 & $\begin{array}{l}9 . \\
5\end{array}$ & 0 & 0 & 10 & 7.1 & 59 & $\begin{array}{c}42 . \\
2\end{array}$ & 71 & $\begin{array}{c}50 . \\
7\end{array}$ \\
\hline
\end{tabular}

ICT trained teachers $(n=210 . \%=100)$

Non-ICT trained teachers $(n=140 . \%=100)$

The information presented in Table 4.2 indicated that 91.9 percent and 8.1 percent of ICT trained teachers strongly agreed and agreed with the statement that they used ICT to prepare schemes of work compared to 36.4 percent and 27.9 percent of the Non-ICT trained teachers who strongly agreed and agreed with the statement respectively. None of ICT trained teachers disagreed or strongly disagreed with the statement that they used ICT to prepare schemes of work compared to 21.4 percent and 14.3 percent of NonICT trained teachers who disagreed and strongly disagreed with the statement respectively. None of the Non-ICT trained teachers strongly agreed and agreed with the statement that they used ICT to write lesson plans compared to 91.9 percent and 8.1 percent of ICT trained teachers who strongly agreed and agreed with the statement respectively. To the contrary, 40 percent and 60 percent of Non-ICT trained teachers disagreed and strongly disagreed with the statement that they used ICT to write lesson plans, while none of the ICT trained teachers disagreed or strongly disagreed with the statement respectively.

The data also showed that 85.2 percent of ICT trained teachers strongly agreed with the statements that they used ICT to write lesson notes and prepare records of work respectively, while none of the Non-ICT trained teachers strongly agreed with the statements. 9.3 percent and 7.1 percent of Non-ICT trained teachers agreed with the statements that they used ICT to write lesson notes and prepare records of work respectively, compared to 14.8 percent of ICT trained teachers who agreed with the statements respectively. None of the ICT trained teachers disagreed with the statements that they used ICT to write lesson notes and prepare records of work respectively, compared to 42.8 percent and 45 percent of Non-ICT trained teachers who disagreed with the statements respectively. In addition, none of the ICT trained teachers strongly disagreed with the statements that they used ICT to write lesson notes and prepare records of work compared to 47.9 percent of Non-ICT trained teachers who strongly disagreed with the statements respectively.

Similarly, 71.4 percent and 14.3 percent of ICT trained teachers strongly agreed and agreed with the statement that they used ICT to research 
lesson content respectively, while 31.4 percent and 37.1 percent of Non-ICT trained teachers had similar views respectively. To the contrary, 7.1 percent of ICT trained teachers disagreed and strongly disagreed with the statement that they used ICT to research lesson content respectively, compared to 18.6 percent and 12.9 percent of Non-ICT trained teachers who disagreed and strongly disagreed with the statement respectively. The data also indicated that, 55.2 percent and 22.9 percent of ICT trained teachers strongly agreed and agreed with the statement that they used ICT to access educational materials from online data base (E.g. websites etc.) respectively, compared to 28.6 percent and 37.1 percent of Non-ICT trained teachers who had similar views respectively. However, 12.4 percent and 9.5 percent of ICT trained teachers disagreed and strongly disagreed with the statement that they used ICT to access educational materials from online data base (E.g. websites etc.) respectively; 21.4 percent and 12.9 percent of Non-ICT trained teachers had similar views respectively.

Further the information indicated that 57.1 percent of ICT trained teachers strongly agreed with the statement that they used ICT to prepare PowerPoint presentations compared to 75 percent of Non-ICT trained teachers who strongly disagreed with the statement. None of the Non-ICT trained teachers agreed with the statement that they used ICT to prepare PowerPoint presentations compared to 23.8 of ICT trained teachers who agreed with the statement. Similarly, 10.5 percent of ICT trained teachers and 25 percent of Non-ICT trained teachers disagreed with the statement that they used ICT to prepare PowerPoint presentations respectively.

The analysis also showed 51.9 percent and 30 percent of ICT teachers strongly agreed and agreed with the statements that they used ICT to prepare lesson attendance sheets, sound/audio clips, video clips, and images for lessons respectively; none of the Non-ICT trained teachers strongly agreed with the statements while only 7.1 percent of them agreed with the statements respectively. To the contrary, 42.2 percent and 50.7 percent of Non-ICT trained teachers disagreed and strongly disagreed with the statements that they used ICT to prepare lesson attendance sheets, sound/audio clips, video clips, and images for lessons respectively compared to 8.6 percent and 9.5 percent of ICT trained teachers who had similar views respectively.

This connoted that ICT trained teachers had the relevant ICT training thus intensely utilized technology and ICT software to ease and heighten their content preparation for quality teaching resources and innovative pedagogy. This is in line with a comparative study conducted by Sigales (2013) in 22 secondary schools in Singapore which concluded that ICT trained teachers' application of technology in content preparation enabled the creation of multimedia based interactive and experimental instructional materials which catered for students with different learning abilities, enhanced access to a wide 
range of educational materials from online sources thus inclusive and quality education.

The Non-ICT trained teachers lowly employed ICT in their content preparation due to lack of formal ICT training on the use of ICT equipment in pedagogy. The low levels of ICT usage in content preparation could also be associated with inadequate ICT equipment, non-serviceable ICT equipment, huge workloads, broad curriculum, and insufficient time to prepare technology-based lessons. This concurs with the findings that Non-ICT trained teachers were deficient of ICT skills to plan technology lessons, sort educational software and explore internet sites for teaching materials, prepare PowerPoint and images for class presentation which resulted to teacher centered classroom activities (Magbagbeola, 2012).

Both ICT and Non-ICT trained teachers embraced ICT in preparing schemes of work which is a professional document for teachers, research lesson content, and access educational materials online thus enhancing their content preparation. This reflected the position held by Lee and Tsai (2010) that ICT and Non-ICT trained teachers used word processor to prepare lesson plans, schemes of work, records of work, and compile lesson materials; In addition they searched different sites for educational resources leading to quality course content and heightened pedagogical practices.

The study further sought to establish the students' views on teachers' usage of ICT skills in content preparation to reinforce the principals and teachers views. They were requested to indicate their responses as; $\mathrm{SA}=$ Strongly Agree, $\mathrm{A}=\mathrm{Agree}, \mathrm{D}=\mathrm{Disagree}$, and $\mathrm{SD}=\mathrm{Strongly}$ Disagree. The results were presented in Table 4.3.

Table 4.3 Students' views on teachers' use of ICT skills in content preparation

\begin{tabular}{|c|c|c|c|c|c|c|c|c|c|c|c|c|c|c|}
\hline \multirow[t]{2}{*}{ Responses } & \multicolumn{3}{|c|}{ SA } & \multicolumn{3}{|c|}{$\mathbf{A}$} & \multicolumn{3}{|c|}{ D } & \multicolumn{3}{|c|}{ SD } & \multicolumn{2}{|c|}{ Total } \\
\hline & $\mathbf{n}$ & & $\%$ & I & & $\%$ & & n & $\%$ & $\mathbf{n}$ & & $\%$ & $\mathbf{n}$ & $\%$ \\
\hline Teachers use ICT to write lesson notes & 1 & & 36. & c & & 24. & & 8 & 21. & 6 & & 17. & 3 & 1 \\
\hline & 40 & 8 & & 3 & 5 & & 0 & 1 & 1 & 7 & 6 & & 80 & 00 \\
\hline Teachers use ICT to research lesson & 1 & & 28. & c & & 26. & 3 & 9 & 25 & 7 & & 20 & 3 & 1 \\
\hline content & 10 & 9 & & 9 & 1 & & 5 & & & 6 & & & 80 & 00 \\
\hline Teachers use ICT to access educational & 1 & & 26. & 1 & & 27. & se & 9 & 23. & 8 & & 21. & 3 & 1 \\
\hline $\begin{array}{l}\text { materials from online data base (E.g. } \\
\text { Websites etc.) }\end{array}$ & 02 & 8 & & 06 & 9 & & 0 & & 7 & 2 & 6 & & 80 & $\mathbf{0 0}$ \\
\hline ICT to prepare power point & 9 & & 23. & c & & 25 & se & 9 & 24. & 1 & & 27. & 3 & 1 \\
\hline present: & 0 & 7 & & 5 & & & 2 & 2 & 2 & 03 & 1 & & 80 & 00 \\
\hline Teachers use ICT to prepare sound/audio & 9 & & 25. & s & & 24 & (se & & 24. & 1 & & 26. & 3 & 1 \\
\hline clips & 7 & 5 & & 1 & & & 2 & 2 & 2 & 00 & 3 & & 80 & 00 \\
\hline Teachers use ICT to prepare video clips & 9 & & 23. & s & & 25 & & & 24. & 1 & & 27. & 3 & 1 \\
\hline for lessons & 0 & 7 & & 5 & & & 2 & 2 & 2 & 03 & 1 & & 80 & 00 \\
\hline Teachers use ICT to prepare images for & 9 & & 26. & s & & 23. & se & 9 & 23. & 1 & & 26. & 3 & 1 \\
\hline lessons & 9 & 1 & & 0 & 7 & & 0 & 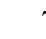 & 7 & 01 & 5 & & 80 & 00 \\
\hline
\end{tabular}

The analysis in Table 4.3 showed that 36.8 percent and 24.5 percent of the students strongly agreed and agreed with the statement that both ICT and 
Non-ICT trained teachers used ICT to write lesson notes respectively, compared to 21.1 percent and 17.6 percent who disagreed and strongly disagreed with the statement respectively. In addition, 25 percent and 20 percent of the students disagreed and strongly disagreed with the statement that the teachers used ICT to research lesson content respectively, while 28.9 percent and 26.1 percent strongly agreed and agreed with the statement respectively.

Further, the information indicated that 21.6 percent of the students strongly disagreed with the statement that both ICT and Non-ICT trained teachers used ICT to access educational materials from online data base (E.g. Websites etc.) compared to 26.8 percent who strongly agreed with the statement. On the same, 27.9 percent of the students agreed with the statement that teachers used ICT to access educational materials from online data base (E.g. Websites etc.), compared to 23.7 percent who disagreed with the statement.

Similarly, 23.7 percent and 25 percent of the students strongly agreed and agreed with the statements that teachers used ICT to prepare PowerPoint presentations and video clips for lessons respectively, compared to 24.2 percent and 27.1 percent who disagreed and strongly disagreed with the statements respectively. Likewise, 25.5 percent and 24 percent of the students strongly agreed and agreed with the statement that teachers used ICT to prepare sound/audio clips for lessons respectively compared to 24.2 percent and 26.3 percent who disagreed and strongly disagreed with the statement respectively. The analysis also showed that 26.1 percent of the students strongly agreed with the statement that both ICT and Non-ICT trained teachers used ICT to prepare images for lessons compared to 26.5 percent who strongly disagreed with the statement. Similarly, 23.7 percent of the students agreed with the statement that teachers used ICT to prepare images for lessons, while 23.7 percent of the students disagreed with the statement.

These sentiments were similar to those of the principals and teachers which signified that both ICT and Non-ICT trained teachers applied ICT skills variedly in preparing content for their teaching and learning activities. The findings concurred with a study conducted by Heick (2016) which found out that in Turkish schools both ICT and Non-ICT trained teachers were knowledgeable in basic ICT but the levels of integration in lesson preparation were very low due to huge workloads and insufficient time to use ICT tools. The teachers lowly employed ICT in preparing video clips and images to merge with the subject content, develop lesson attendance sheets, and records of work which negatively influenced their creativity, innovation, and students' academic achievements.

\subsection{Observation schedule on content preparation by teachers}


Further the researchers carried out an observation on teachers' use of ICT skills in content preparation. The findings were as shown in Table 4.4.

Table 4.4 Observation results on teachers' use of ICT skills in content preparation

\begin{tabular}{|c|c|c|c|c|c|c|c|c|c|c|c|c|}
\hline \multirow{3}{*}{ Response } & \multicolumn{6}{|c|}{ ICT trained teachers } & \multicolumn{6}{|c|}{ Non-ICT trained teachers } \\
\hline & \multicolumn{2}{|c|}{$\begin{array}{c}\text { ICT } \\
\text { compliance }\end{array}$} & \multicolumn{2}{|c|}{$\begin{array}{c}\text { Non-ICT } \\
\text { compliance }\end{array}$} & \multicolumn{2}{|c|}{ Total } & \multicolumn{2}{|c|}{$\begin{array}{c}\text { ICT } \\
\text { compliance }\end{array}$} & \multicolumn{2}{|c|}{$\begin{array}{c}\text { Non-ICT } \\
\text { compliance }\end{array}$} & \multicolumn{2}{|c|}{ Total } \\
\hline & $\mathbf{n}$ & $\%$ & $\mathbf{n}$ & $\%$ & $\mathbf{N}$ & $\%$ & $\mathbf{n}$ & $\%$ & $\mathbf{n}$ & $\%$ & $\mathbf{n}$ & $\%$ \\
\hline Lesson plans & 210 & 100 & 0 & 0 & 210 & 100 & 13 & 9.3 & 127 & 90.7 & 140 & 100 \\
\hline Schemes of work & 210 & 100 & 0 & 0 & 210 & 100 & 125 & 89.3 & 15 & 10.7 & 140 & 100 \\
\hline Students worksheets & 210 & 100 & 0 & 0 & 210 & 100 & 115 & 82.1 & 25 & 17.9 & 140 & 100 \\
\hline Lesson notes & 170 & 80.9 & 40 & 19.1 & 210 & 100 & 13 & 9.3 & 127 & 90.7 & 140 & 100 \\
\hline Hand outs & 90 & 42.9 & 120 & 57.1 & 210 & 100 & 40 & 28.6 & 100 & 71.4 & 140 & 100 \\
\hline Records of work & 210 & 100 & 0 & 0 & 210 & 100 & 20 & 14.3 & 120 & 85.7 & 140 & 100 \\
\hline PowerPoint slides & 170 & 80.9 & 40 & 19.1 & 210 & 100 & 0 & 0 & 140 & 100 & 140 & 100 \\
\hline Video clips/Visual clips & 189 & 90 & 21 & 10 & 210 & 100 & 22 & 15.7 & 118 & 84.3 & 140 & 100 \\
\hline Simulation clips & 90 & 42.9 & 120 & 57.1 & 210 & 100 & 40 & 28.6 & 100 & 71.4 & 140 & 100 \\
\hline $\begin{array}{l}\text { Games and Role play } \\
\text { clips }\end{array}$ & 189 & 90 & 21 & 10 & 210 & 100 & 90 & 64.3 & 50 & 35.7 & 140 & 100 \\
\hline Audio clips & 180 & 85.7 & 30 & 14.3 & 210 & 100 & 12 & 8.6 & 128 & 91.4 & 140 & 100 \\
\hline Images & 180 & 85.7 & 30 & 14.3 & 210 & 100 & 10 & 7.1 & 130 & 92.9 & 140 & 100 \\
\hline
\end{tabular}

The data captured in Table 4.4 revealed that ICT trained teachers extensively integrated technology in their content preparation as evidenced by 100 percent of them found having ICT compliant lesson plans compared to 9.3 percent of Non-ICT trained teachers who had ICT compliant lesson plans; while 90.7 percent of Non-ICT trained teachers had non-ICT compliant lesson plans. All the ICT trained teachers had ICT compliant schemes of work compared to 89.3 percent of Non-trained teachers who had ICT compliant schemes of work; only 10.7 percent of Non-ICT trained teachers were not having ICT compliant schemes of work. In addition, 100 percent of ICT trained teachers were found having ICT compliant student's worksheets compared to 82.1 percent of Non-ICT trained teachers who had ICT compliant student's worksheets.

Further, the data indicated that 80.9 percent of ICT trained teachers had ICT compliant lesson notes compared to 9.3 percent of Non-ICT trained teachers who also had ICT compliant lesson notes. To the contrary, 90.7 percent of Non-ICT trained teachers and 19.1 percent of ICT trained teachers used lesson notes which were not ICT compliant respectively. Similarly, 57.1 percent of ICT trained teachers and 71.4 percent of Non-ICT trained teachers had non-ICT compliant handouts respectively compared to 42.9 percent of ICT trained teachers and 28.6 of Non-ICT trained teachers who had ICT compliant handouts respectively. All the ICT trained teachers had ICT 
compliant records of work compared to 14.3 percent of Non-ICT trained teachers who had the same; 85.7 percent of Non-ICT trained teachers were not using ICT compliant records of work. None of the Non-ICT trained teachers used PowerPoint slides compared to 80.9 percent of ICT trained teachers who used PowerPoint slides in content preparation.

The analysis also showed that 90 percent of ICT trained teachers used video/visual clips in content preparation compared to 15.7 percent of Non-ICT trained teachers who used video/visual clips; 84.3 percent of Non-ICT trained teachers were found not using video/visual clips in content preparation compared to 10 percent of ICT trained teachers. In addition, 57.1 percent of ICT trained teachers and 71.4 percent of Non-ICT trained teachers did not use simulation clips respectively compared to 42.9 percent of ICT trained teachers and 28.6 percent of Non-ICT trained teachers who were found using simulation clips in content preparation respectively.

Similarly, 90 percent of ICT trained teachers and 64.3 percent of NonICT trained teachers used games and role play clips in content preparation respectively. However, 35.7 percent of Non-ICT trained teachers and 10 percent of ICT trained teachers did not use games and role play clips in content preparation respectively. The observation results also indicated that 85.7 percent of ICT trained teachers used audio clips to prepare lessons, compared to 8.6 percent of Non-ICT trained teachers who used audio clips to prepare lessons respectively. To the contrary, 91.4 percent of Non-ICT trained teachers did not use audio clips in content preparation compared to 14.3 percent of ICT trained teachers. 85.7 percent of ICT trained teachers used images in lesson preparation compared to 7.1 percent of Non-ICT trained teachers; however, 92.9 percent of Non-ICT trained teachers did not use ICT compliant images in content preparation compared to 14.3 percent of ICT trained teachers.

This implied that both ICT and Non-ICT trained teachers employed ICT skills in their content preparation though with variations. The ICT trained teachers greatly integrated ICT in their content preparation due to the ICT training they had acquired coupled with adequacy and serviceable ICT equipment in their schools. The Non-ICT trained teachers were not competent enough to prepare PowerPoint slides, video/visual clips, audio clips, and images and integrate them in their pedagogical practices. Non-ICT trained teachers lowly utilized ICT in preparation of lesson plans and notes which could be due to inadequacy and non-serviceable ICT equipment in the schools. This finding concurs with the views of the principals, teachers, and students.

\subsection{Document analysis on content preparation}

In addition, the study further considered the use of document analysis guide for data triangulation purposes. The researchers sought to find out the 
availability of teachers' particulars for content preparation and if they included

ICT related resources. The findings were as presented in Table 4.5.

Table 4.5 Availability of teachers' particulars for content preparation and inclusion of ICT related resources

\begin{tabular}{|c|c|c|c|c|c|c|c|c|c|c|c|c|}
\hline \multirow{3}{*}{ Response } & & & \multicolumn{4}{|c|}{ ICT trained teachers } & \multicolumn{6}{|c|}{ Non-ICT trained teachers } \\
\hline & \multicolumn{2}{|l|}{ Yes } & \multicolumn{2}{|c|}{ No } & \multicolumn{2}{|c|}{ Total } & \multicolumn{2}{|c|}{ Yes } & \multicolumn{2}{|c|}{ No } & \multicolumn{2}{|c|}{ Total } \\
\hline & $\mathbf{n}$ & $\%$ & $\mathbf{n}$ & $\%$ & $\mathbf{N}$ & $\%$ & $\mathbf{n}$ & $\%$ & $\mathbf{n}$ & $\%$ & $\mathbf{n}$ & $\%$ \\
\hline Lesson plans & 210 & 100 & 0 & 0 & 210 & 100 & 13 & 9.3 & 127 & 90.7 & 140 & 100 \\
\hline Schemes of work & 210 & 100 & 0 & 0 & 210 & 100 & 125 & 89.3 & 15 & 10.7 & 140 & 100 \\
\hline Students worksheets & 210 & 100 & 0 & 0 & 210 & 100 & 115 & 82.1 & 25 & 17.9 & 140 & 100 \\
\hline Lesson notes & 190 & 90.5 & 20 & 9.5 & 210 & 100 & 13 & 9.3 & 127 & 90.7 & 140 & 100 \\
\hline Hand outs & 90 & 42.9 & 120 & 57.1 & 210 & 100 & 40 & 28.6 & 100 & 71.4 & 140 & 100 \\
\hline Records of work & 210 & 100 & 0 & 0 & 210 & 100 & 20 & 14.3 & 120 & 85.7 & 140 & 100 \\
\hline PowerPoint slides & 170 & 80.9 & 40 & 19.1 & 210 & 100 & 0 & 0 & 140 & 100 & 140 & 100 \\
\hline Video clips/Visual clips & 189 & 90 & 21 & 10 & 210 & 100 & 22 & 15.7 & 118 & 84.3 & 140 & 100 \\
\hline Simulation clips & 90 & 42.9 & 120 & 57.1 & 210 & 100 & 40 & 28.6 & 100 & 71.4 & 140 & 100 \\
\hline $\begin{array}{l}\text { Games and Role play } \\
\text { clips }\end{array}$ & 189 & 90 & 21 & 10 & 210 & 100 & 90 & 64.3 & 50 & 35.7 & 140 & 100 \\
\hline Audio clips & 180 & 85.7 & 30 & 14.3 & 210 & 100 & 12 & 8.6 & 128 & 91.4 & 140 & 100 \\
\hline Images & 180 & 85.7 & 30 & 14.3 & 210 & 100 & 10 & 7.1 & 130 & 92.9 & 140 & 100 \\
\hline
\end{tabular}

The information contained in Table 4.5 indicated that 100 percent of ICT trained teachers had ICT compliant lesson plans compared to 90.7 percent of Non-ICT trained teachers who had non-ICT compliant lesson plans; 9.3 percent of Non-ICT trained teachers had ICT compliant lesson plans. In addition, 100 percent of ICT trained teachers had ICT compliant student's worksheets and schemes of work compared to 89.3 percent and 52.1 percent of Non-ICT trained teachers who had same ICT compliant documents respectively. However, 10.7 percent and 17.9 percent of Non-ICT trained teachers were found having non-ICT compliant student's worksheets and schemes of work respectively. The analysis also showed that 90.5 percent of ICT trained teachers had ICT compliant lesson notes compared to 9.3 percent of Non-ICT trained teachers who had ICT compliant lesson notes. However, 90.7 percent of Non-ICT trained teachers had lesson notes which were not ICT compliant, compared to 9.5 percent of ICT trained teachers who had lesson notes which were not ICT compliant.

To the contrary, 57.1 percent of ICT trained teachers and 71.4 percent of Non-ICT trained teachers had non-ICT compliant handouts respectively; compared to 42.9 percent of ICT trained teachers and 28.6 percent of NonICT trained teachers had who ICT compliant handouts respectively. None of the ICT trained teachers had non-ICT compliant records of work compared to 
85.7 percent of Non-ICT trained teachers who had non-ICT compliant records of work. All the Non-ICT trained teachers were not found having PowerPoint slides compared to 80.9 percent of ICT trained teachers who had PowerPoint slides; 19.1 percent of ICT trained teachers did not have PowerPoint slides. Further, the information revealed that, 90 percent of ICT trained teachers had video clips/visual clips compared to 15.7 percent of Non-ICT trained teachers. However, 84.3 percent of Non-ICT trained teachers did not possess video clips/visual clips compared to 10 percent of ICT trained teachers who did not have video clips/visual clips. Likewise, 57.1 percent of ICT trained teachers and 71.4 of Non-ICT trained teachers did not have simulation clips respectively compared to 42.9 percent of ICT trained teachers and 28.6 of Non-ICT trained teachers who had simulation clips for content preparation respectively. In addition, 85.7 percent of ICT trained teachers had audio clips and images for lesson preparation respectively compared to 8.6 percent and 7.1 percent of Non-ICT trained teachers who had audio clips and images respectively. However, 91.4 percent and 92.9 percent of Non-ICT trained teachers did not have audio clips and images respectively, compared to 14.3 percent of ICT trained teacher who were not found having audio clips and images respectively.

This implied that the availability of teachers' particulars for content preparation and inclusion of ICT related resources differed amongst the ICT and Non-ICT trained teachers which influenced their pedagogical practices variedly. The findings confirmed the opinions of the principals, teachers, students, and the findings of the observation schedule on ICT and Non-ICT trained teachers' usage of ICT skills and equipment for content preparation.

\subsection{Hypothesis testing and analysis}

The study also sought to establish the influence of ICT integration on content preparation by teachers in secondary schools. This was done through hypothesis testing and analysis.

\section{$\mathrm{H}_{1}$ ICT integration does not significantly influence content preparation by ICT and Non-ICT trained teachers in secondary schools in Machakos County, Kenya.}

In order to establish whether there was a relationship between ICT integration and content preparation by teachers, a simple regression test was carried out between teachers' use of ICT skills and responses from questions on content preparation by both ICT and Non-ICT trained teachers. A coefficient of correlation (r) was calculated which established the presence, strength, direction, and level of correlation. 
The coefficient of correlation (r) was squared to obtain the coefficient of determination which explained the degree of association between ICT integration and content preparation by ICT and Non-ICT trained teachers. The results were as illustrated in Table 4.6.

Table 4.6 Simple regression model summary on the influence of ICT integration on content preparation by ICT and Non-ICT trained teachers

\begin{tabular}{cccc}
\hline Model & $(\mathbf{r})$ & $\left.\mathbf{( r}^{2}\right)$ & Sig. (b) \\
\hline ICT trained teachers & 0.859 & 0.738 & 0.002 \\
Non-ICT trained teachers & 0.578 & 0.334 & 0.045 \\
\hline
\end{tabular}

\section{Significant at the 0.05 level (2-tailed) $\mathrm{df}=1$}

(a) Constant predictor: ICT integration (b) Dependent variable: Content preparation

The information in Table 4.6 showed that the coefficient of correlation (r) for ICT trained teachers was 0.859 implying a very strong relationship between the predictor variable (ICT integration) and teachers' content preparation. The coefficient of determination $\left(\mathrm{r}^{2}\right)$ was 0.738 . This implied that about $73.8 \%$ of the variation in the content preparation by ICT trained teachers was explained by ICT integration in content preparation. Similarly for NonICT trained teachers the (r) value was 0.578 indicating a moderate relationship between ICT integration and teachers' content preparation. The value of $\left(\mathrm{r}^{2}\right)$ was at level 0.334 showing that about $33.4 \%$ of the variation in the content preparation by Non-ICT trained teachers could be explained by ICT integration in content preparation.

The data also showed that the significance level of teachers' integration of ICT in content preparation for ICT trained teachers was highly significant at $p$ level 0.002 . The relationship indicated that ICT integration resulted to high levels of use of ICT skills in content preparation by ICT trained teachers. Similarly the significance level amongst Non-ICT trained teachers was significant at $p$ value 0.045 ; this indicated that ICT integration influenced Non-ICT trained teachers' content preparation though at a moderate level.

\section{Conclusions and Recommendations}

The study concluded that ICT integration significantly influenced teachers' content preparation by ICT and Non-ICT trained teachers. ICT trained teachers' integration of ICT in their content preparation was significantly higher at (p) 0.002 than their Non-ICT trained counterparts at (p) 0.045 . The study concluded that ICT trained teachers integrated ICT in their content preparation more than Non-ICT trained teachers in secondary schools in Machakos County, Kenya. Hence the null hypothesis was rejected. 
Based on the findings and conclusions the study recommended that, the Ministry of Education (MOE) should intensify ICT training in teacher training institutions to ensure that all secondary school teachers acquire the relevant ICT skills to fully integrate and use ICT in their pedagogical practices. The Ministry of Education (MOE) and other ICT training agencies should provide ICT in-service training programs to ensure that all teachers acquire ICT skills to utilize ICT in content preparation for quality education.

\section{References:}

1. Amuko, S. (2015). Pedagogical Practices in Integration of ICT in Teaching and Learning Mathematics, in Secondary Schools in Nairobi County, Kenya. IOSR Journal of Mathematics (IOSR-] JM), 11 (5), 20-23.

2. Ateş, M., Çerçi, A., \& Derman, S. (2015). Content analysis of Turkish course videos in educational informatics network. Sakarya University Journal of Education, 5(3), 105-117.

3. Badri, M. A. (2014). Technology Readiness of School Teachers: An Empirical Study of Measurement and Segmentation. Journal of Information Technology Education: Research, 13, 257-275. Retrieved August 25, 2016 from https://www.informingscience.org/Publications/2082

4. Greaves, T.W. (2012). Revolutionizing Education through Technology: The Project RED Road map for Transformation, ISTE. http://www.projectred.org

5. Heick, T. (2016). How 21 st Century Thinking Is Just Different. Teach thought. http://www. Teacher thought.com/critical thinking/ how $21^{\text {st }}$ century thinking is different.

6. Ishizuka H (2013). The effects of ICT Environment on Teachers' Attitudes and Technology Integration in Spain and the US. Journal of Information Technology Education: Innovations in Practice12 (1): 29 43.

7. Kombo, N. (2013). Enhancing Kenyan Students Learning Through ICT Tools for Teachers. Centre for Educational Innovation. An Initiative for Results for Development Institute

8. Kozma, R. B., \& Vota, W. S. (2014). ICT in Developing Countries: Policies, Implementation, and Impact. New York, NY: Springer.

9. Lee, M.H., and Tsai, C. - C. (2010). Exploring Teachers' Perceived Self Efficacy and Technological Pedagogical Content Knowledge with Respect to Educational Use of the World Wide Web. Instructional Science, 38 (1), 1-21. 
10. Liu, S-H 2011, 'Factors related to pedagogical beliefs of teachers and technology integration', Computers \& Education, vol. 56, no. 4, pp. 1012-1022.

11. Magbagbeola, N. O. (2012). Information and Communication Technology in Nigeria: A Critical Assessment.

12. MOE (2013). Curriculum Guide for ICT Integration in Education. Digital Literacy Programme. A New Assessment Paradigm Using ICT, 2013-2016.

13. Passi, B K. (2014). Training in Technology-Pedagogy Integration. Presentation to Experts' Meeting on Teachers/Facilitators Training in Technology Pedagogy Integration, Bangkok, Thailand. June 18-20.

14. Sigalés, C. (2013). Teachers' Perceptions of ICT Application in Pedagogical Practices - A Comparative Study of Singapore Schools. Electronic Journal of Research in Educational Psychology 11(3): 787808.

15. Tezci, E. (2011). Factors that Influence Pre-service Teachers' ICT Usage in Education. European Journal of Teacher Education, 34, 483499.

16. UNESCO. (2015). ICT Competency Standards for Teachers: Competency Standards Modules. UNESCO, Paris. 